\title{
pH-driven solubilization and isoelectric precipitation of proteins from the brown seaweed Saccharina latissima-effects of osmotic shock, water volume and temperature
}

\author{
Jenny Veide Vilg ${ }^{1}$ (D) Ingrid Undeland ${ }^{1}$
}

Received: 6 July 2016/Revised and accepted: 7 September 2016/Published online: 23 September 2016

(C) The Author(s) 2016. This article is published with open access at Springerlink.com

\begin{abstract}
In the light of the global search for novel and sustainable protein sources, macroalgal proteins are becoming an attractive target. To date, mainly red and green macroalgae have been investigated in this respect, whereas the brown species are less studied, possibly because of the lower content of protein. In a biorefinery context, however, the protein content of brown macroalgae can still be economically interesting due to fast growth and the possibility to co-extract other compounds, such as alginates. The aim of this study was to develop a simple, scalable $\mathrm{pH}$ shift-based protein isolation technique applicable on wet Saccharina latissima biomass. Factors investigated were extraction volume, temperature, protein solubilization $\mathrm{pH}$, osmoshock pretreatment and protein precipitation $\mathrm{pH}$. Maximum protein solubility was obtained at $\mathrm{pH} 12$, where $34 \%$ of the total protein content could be extracted with 5.56 volumes of extraction solution (20 volumes on dry weight (dw) basis). Osmoshocking significantly increased the yield, and 20, 40 and 60 volumes of water (dw basis) gave 45.1, 46.8 and $59.5 \%$ yield, respectively. The temperature during osmoshocking did not significantly affect the extraction yield, and extended time (16 vs. 1 or $2 \mathrm{~h}$ ) reduced protein yield. Precipitation of solubilized proteins was possible below $\mathrm{pH} 4$; the highest precipitation yield, $34.5 \%$, was obtained at $\mathrm{pH} 2$. After combined alkaline extraction and acid precipitation, $16.01 \%$ of the Saccharina proteins were recovered, which can be considered acceptable in comparison to other studies on algae but leaves some room for
\end{abstract}

Jenny Veide Vilg

jenny.vilg@cit.chalmers.se

1 Food and Nutrition Science, Biology and Biological Engineering, Chalmers University of Technology, 41296 Gothenburg, Sweden improvement when compared to protein extraction from, for instance, soy.

Keywords Saccharina latissima $\cdot$ Phaeophyceae · Protein · Seaweed $\cdot$ Solubility $\cdot$ Precipitation $\cdot \mathrm{pH}$

\section{Background}

The growing global human population, with increasing demands for nutrient-rich foods, constitutes a great challenge when it comes to adequate protein supply, both for human consumption and for feed that can be converted into animal source protein (Wu et al. 2014). Novel sources of protein will make an important contribution to the world's supply in the future, but we need to consider not only the productivity, but also sustainability concerns to avoid depletion of water and land reserves (Boland et al. 2013). The interest in marine seaweeds as a substrate for biorefining has increased, with products such as bioethanol (Daroch et al. 2013) biogas (Hughes et al. 2012), polymers (Bixler and Porse 2011), antioxidants (Jónsdóttir et al. 2016) and proteins (e.g. Harnedy and FitzGerald 2013) in focus. An important advantage with using seaweed biomass as a substrate is that their cultivation does not require arable land, nor irrigation, fertilization or pesticides, which increases the potential for sustainable production. There is a varying content of protein in macroalgae, depending on species, and the brown kelps, which are most commonly described in biorefinery contexts, generally contain high concentrations of carbohydrates but have a lower protein content (Fleurence 1999). However, considering their high productivity (Kraan 2013), the yield per cultivation area could still be competitive as compared to other species. 
Macroalgal proteins have been reported to have an amino acid profile suitable for human consumption (Maehre et al. 2014; Marinho et al. 2015), and eating seaweeds is a part of the cuisine in several countries. The bioavailability of the algal proteins has been discussed; for instance, the soluble fibres of seaweed have been shown to inhibit the digestibility of protein (Horie et al. 1995). This gives a good reason for extracting the protein fraction from the rest of the algal matrix, before using it for consumption. Other positive effects of extraction are that the end product becomes more nutrient dense and that other fractions can be separated in parallel, as in a biorefinery concept, which increases the economic value (Hou et al. 2015). There are few reports on methods for extraction of seaweed proteins, especially from the brown seaweeds. Jordan and Vilter (1991) showed how the occurrence of phenolic compounds, pigments and large amounts of polyanionic cell wall mucilages, mainly consisting of alginates, renders protein extraction from this class of seaweed difficult.

The fact that proteins in water obtain net positive or negative charges when adjusted to extremely acid or alkaline conditions, respectively, can be the basis for their isolation. This is since the strong repulsions caused by like charges favour protein solubilization, whereupon non-soluble matter can be removed, e.g. by centrifugation. Alkaline solubilization followed by isoelectric protein precipitation is applied, for example, in the isolation of soy protein (Rickert et al. 2004) and wheat protein (Liu et al. 2013). Also, in the early 2000s, acid or alkaline solubilization, followed by removal of non-solubles and isoelectric precipitation, was introduced as a principle to isolate boneless and nearly lipid-free proteins from complex raw materials like whole fish or fish by-products (e.g. Hultin and Kelleher 1999, 2000, 2001; Hultin et al. 2000; Undeland et al. 2002). Performing the whole procedure under cold conditions allowed the fish proteins to retain their technical functionality, including their capacity to form a gel. This procedure, which often goes under the name 'pH shift method,' has also been applied, e.g. to shellfish (Vareltzis and Undeland 2012) and recently to microalgae (Cavonius et al. 2015, 2016).

Little has been done on $\mathrm{pH}$ shift-like processing of seaweed; the few papers that exist are on red seaweeds, Palmaria palmata (Harnedy and FitzGerald 2013, 2015) and Kappaphycus alvarezii (Doty) (Kumar et al. 2014), various species of green seaweed (Fleurence et al. 1995; Kandasamy et al. 2012), or subtropical brown seaweeds (three Sargassum species) (Wong and Cheung 2001). Kandasamy et al. (2012), Kumar et al. (2014) and Wong and Cheung (2001), however, precipitated the proteins with ammonium sulphate, which then required a dialysis step. Fleurence et al. (1995) and Harnedy and FitzGerald (2013) focused only on the first part of the process, the alkaline solubilization, with and without osmotic shock, high shear treatments or addition of polysaccaridase enzymes (e.g. Celluclast $1.5 \mathrm{~L}$ and Shearzyme $500 \mathrm{~L}$ ), to break down the cellular structures. The authors, however, concluded that since high enzyme/substrate ratios were required, applying these polysaccharidases may not be feasible for the extraction of intact $P$. palmata proteins. In some of the mentioned studies (e.g. Kumar et al. 2014), the water-soluble proteins have been removed in a first step, at the end of the osmotic shock treatment, and have then been combined with the alkali-soluble ones prior to precipitation. Several studies have also applied reducing agents along with the alkaline solubilization (2-mercaptoethanol or $N$-acetyl-L-cysteine (NAC)) (Wong and Cheung 2001; Kandasamy et al. 2012; Harnedy and FitzGerald 2013; Kumar et al. 2014), e.g. to break S-S bonds. The mentioned studies have also used all dried algae biomass.

To make a protein recovery process economically feasible and easy to apply in industry, a simplistic approach with a minimum amount of low energy steps would be beneficial. Bearing this goal in mind, the aim of the present study was to develop basic settings for a relatively simple $\mathrm{pH}$-driven protein extraction protocol to apply directly on wet brown seaweed biomass. Using Saccharina latissima as a focus species, we wished to evaluate the optimal $\mathrm{pH}$ for protein solubilization, the impact from the water to biomass ratio used and the inclusion of an osmotic shock step varying in time and temperature. Brief investigation of $\mathrm{pH}$-driven precipitation of the extracted proteins was also to be carried out, to develop a full $\mathrm{pH}$ shift process protocol.

\section{Methods}

\section{Materials and general biomass preparation}

The algal biomass used for all experiments in this study was from wild specimens of Saccharina latissima, collected by diving in the archipelago of the Swedish west coast in November 2013. Here, the algae grow in a mildly exposed environment, with a tidal amplitude of $10 \mathrm{~cm}$, temperatures between 6 and $20^{\circ} \mathrm{C}$ and a salinity around $3 \mathrm{psu}$. The fresh biomass was minced using a meat grinder (Bankeryds Maskin $\mathrm{AB}$, Sweden), with three layers of hole plates with openings of 450,5 and $2 \mathrm{~mm}$, respectively, and stored at $-20^{\circ} \mathrm{C}$ in ziplock bags until use. Before the experiments, the algal biomass was weighed in frozen state and distilled water added to the $w / w$ ratio needed for the specific experiment. All experimental biomass was kept on ice during the whole process unless stated otherwise.

\section{Total protein analysis}

For the analysis of total protein concentration of algal biomass or residual pellets, we evaluated six different extraction methods before selecting the one with results corresponding best to a reference Kjeldahl analysis. The material was freeze- 
dried and finely ground in a mortar. Around $50 \mathrm{mg}$ of the powder was added to $1 \mathrm{~mL}$ of extraction liquid and treated as follows: (1) Milli-Q water, $1 \mathrm{~h}$ at room temperature; (2) Milli-Q water, $\mathrm{pH} 11,1 \mathrm{~h}$ at room temperature; (3) Milli-Q water, $1 \mathrm{~h}$ at $80^{\circ} \mathrm{C}$; (4) $2 \% \mathrm{SDS}, 1 \mathrm{mM}$ dithiothreitol (DTT), $100{ }^{\circ} \mathrm{C}, 3 \times 5$ min with mixing by vortex in between; (5) $2 \%$ SDS, $1 \mathrm{mM}$ DTT, $\mathrm{pH} 11,100{ }^{\circ} \mathrm{C}, 3 \times 5$ min with mixing by vortex in between; and (6) $2 \times 500 \mu \mathrm{L} 2 \% \mathrm{SDS}, 1 \mathrm{mM}$ DTT, $\mathrm{pH} 11,100^{\circ} \mathrm{C}, 3 \times 5 \mathrm{~min}$ with mixing by vortex in between (the $2 \times 500-\mu \mathrm{L}$ extracts were pooled). The extracts were separated from the solid residuals by centrifugation at $4{ }^{\circ} \mathrm{C}$, $14,000 \times g$ for $20 \mathrm{~min}$ in a microcentrifuge (Eppendorf 5417R). From the results of the subsequent Lowry analysis, we chose treatment no. 4 as the extraction method for total protein analysis. For protein analyses of final precipitates from the $\mathrm{pH}$ shift experiment, the entire pellets were dissolved in $500 \mu \mathrm{L}$ extraction buffer (i.e. treatment no. 4 ) and boiled for $3 \times 5 \mathrm{~min}$ to denature the proteins before analysis.

The above samples, along with supernatants from the described extraction sequences (initial seaweed extracts, solubilized proteins and precipitated proteins), were analyzed using the DC Protein assay (Bio-Rad), which is based on the Lowry assay (Lowry et al. 1951), in microwell format. Bovine serum albumin was used as a standard, and the reliability of the method for algal biomass was confirmed by comparison with Kjeldahl total protein analysis (Kjeldahl, 1883), using a conversion factor of 5.6 (Bogolitsyn et al. 2014).

\section{Determination of optimal $\mathrm{pH}$ for solubilizing the algal proteins}

To determine the protein solubility at different $\mathrm{pH}$ values, $20 \mathrm{~g}$ algal biomass was mixed with water to a ratio of 1:4 (wet weight) and homogenized with a polytron (UltraTurrax T18 basic) at speed 4 for $2 \mathrm{~min}$. $\mathrm{pH}$ was adjusted to a range of values between 2 and 13 by addition of hydrochloric acid $(\mathrm{HCl})$ or sodium hydroxide $(\mathrm{NaOH})(0.1$ or $1 \mathrm{M})$, and the slurry was left to incubate for $20 \mathrm{~min}$ with stirring on ice. Samples of $1.5 \mathrm{~mL}$ were taken in triplicate, and the supernatant was separated by centrifugation at $8000 \times g$ for $10 \mathrm{~min}$ (Thermo Fisher Scientific, Heraeus Fresco 17, Germany). The concentration of soluble protein was determined by the Lowry method as described previously. Solubility was expressed as protein concentration in the supernatant divided by the total protein concentration in the slurry $\times 100$. The point where maximum solubility was obtained $(\mathrm{pH} 12$, see "Results" section) was used in further trials described.

\section{Development of a protein extraction sequence}

A basic extraction sequence was set up with a wet algal biomass to water ratio of 1:5.56, corresponding to $1: 20$ dry weight biomass/water. Algal biomass (13.22 g) per replicate was suspended in water to a total mass of $50 \mathrm{~g}$ in $200-\mathrm{mL}$ beakers. Thereafter, the suspension was homogenized using a polytron (UltraTurrax T18 basic) for 2 min at speed 4 .

The homogenized biomass was first osmoshocked, i.e. incubated for $2 \mathrm{~h}$ at $4{ }^{\circ} \mathrm{C}$ with shaking at $150 \mathrm{rpm}$ in the Milli-Q water in which it was homogenized. The slurry was then centrifuged at $5525 \times \mathrm{g}$ for $30 \mathrm{~min}$, and the supernatant was separated for analysis of water-soluble proteins (see "Total protein analysis" section). The pellet was resuspended in water to a total of $50 \mathrm{~g}$, adjusting $\mathrm{pH}$ to 12 by adding $1 \mathrm{M} \mathrm{NaOH}$. After incubation for $60 \mathrm{~min}$ at $\mathrm{pH} 12,4{ }^{\circ} \mathrm{C}$ and shaking at $150 \mathrm{rpm}$, the solid fraction was again separated by centrifugation at $5525 \times \mathrm{g}$ for $30 \mathrm{~min}$. The content of alkaline-soluble proteins in the supernatant was analyzed as described previously. The pellet was, when stated, freeze-dried and ground in a mortar before extraction and analysis of total remaining protein.

To optimize the extraction sequence, experiments were carried out with variation in (i) temperature $\left(4,20\right.$ and $50^{\circ} \mathrm{C}$ ), (ii) ratio between amount of biomass and volume of water in the osmoshock step and alkaline extraction (1:20, 1:40, 1:60, as calculated on a biomass dry weight (dw) basis) or (iii) length of osmotic shock $(0,1,2,16 \mathrm{~h}$. The abovedescribed protocol was used as a basis but with specific adjustments for the selected parameters (see Fig. 1 for overview).

\section{Precipitation of alkali-extracted proteins to develop a pH shift process}

For the precipitation experiments, which were designed to develop a $\mathrm{pH}$ shift-based protein extraction method, protein extract was prepared as follows: frozen algal biomass was added to distilled water at a ratio of 1:60 (dry weight, corresponding to 1:11 wet weight algal biomass/water) and homogenized with a polytron as described previously. An incubation step of $1 \mathrm{~h}$ at $20^{\circ} \mathrm{C}$ at the native $\mathrm{pH}(\mathrm{pH}$ 7.2) then followed, for osmotic shock, whereafter the $\mathrm{pH}$ was directly adjusted to $\mathrm{pH} 12$ with $1 \mathrm{M} \mathrm{NaOH}$, without prior separation of the water extract. The homogenate was then incubated at $\mathrm{pH} 12$ at room temperature for $1 \mathrm{~h}$, after which the supernatant was separated by centrifugation at $5525 \times \mathrm{g}\left(4^{\circ} \mathrm{C}\right)$ for $30 \mathrm{~min}$.

Seven millilitre of the supernatant was aliquoted to five $15-\mathrm{mL}$ Falcon tubes, and the $\mathrm{pH}$ was adjusted to values between 2 and 5 with $1 \mathrm{M} \mathrm{HCl}$ in four of the tubes, whereas one was left as control ( $\mathrm{pH} 12)$. The precipitated proteins were subsequently separated by centrifugation at $5525 \times \mathrm{g}\left(4{ }^{\circ} \mathrm{C}\right)$ for $30 \mathrm{~min}$, and both supernatant and precipitate were analyzed for protein concentration as described. The experiment was performed in triplicate.

\section{Salinity analysis of algal biomass}

Eighteen millilitre of Milli-Q water was added to $2 \mathrm{~g}$ of algal biomass in a $50-\mathrm{mL}$ tube and homogenized with a polytron at 
Fig. 1 Protein extraction sequence. The scheme describes the solubilization procedure and gives an overview of the variations in biomass/water ratio, length of osmoshock and temperature. The part shown in dashed lines represents the subsequent precipitation sequence
Wet, minced S. latissima

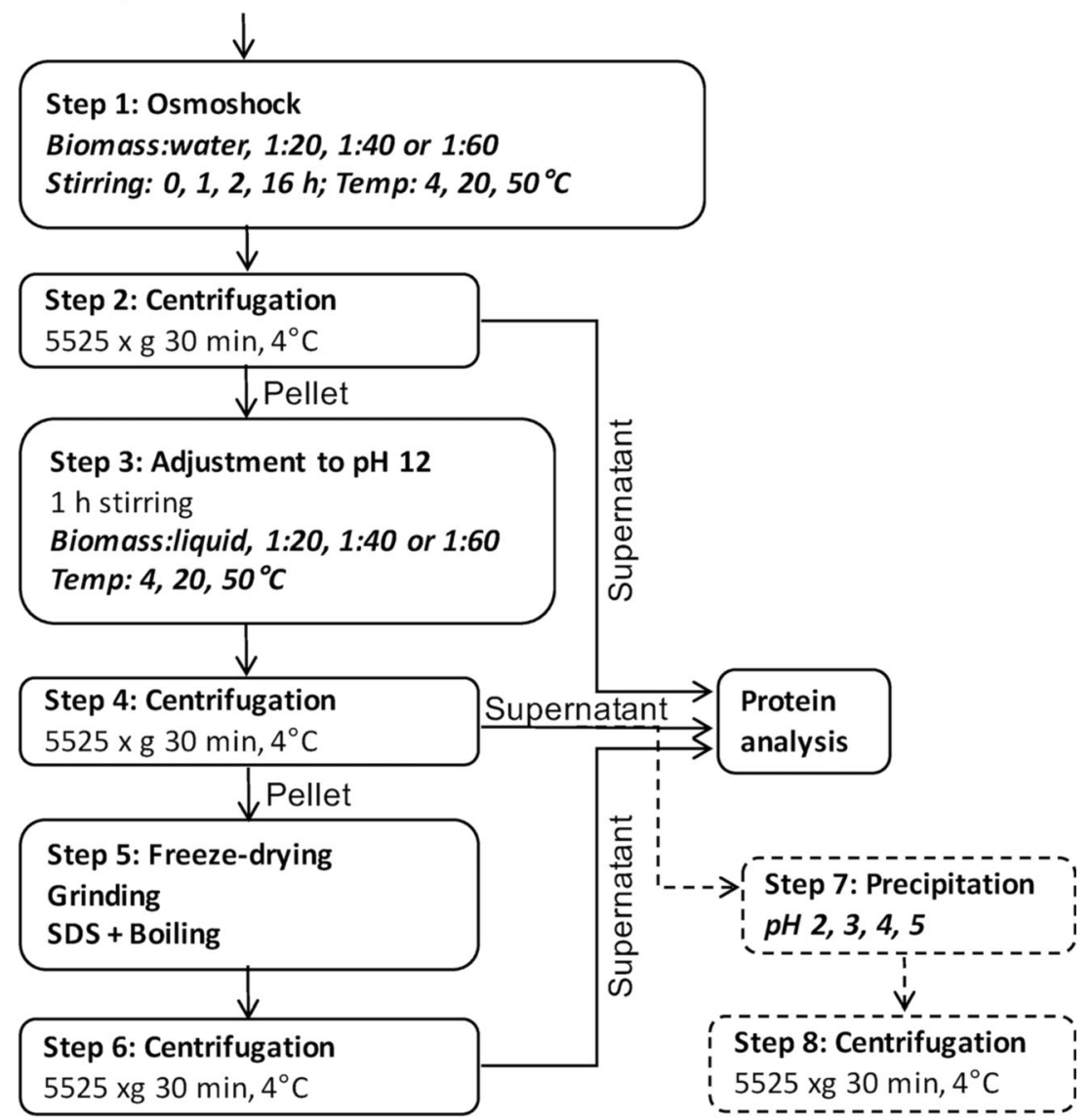

speed 5 for $30 \mathrm{~s}$. The conductivity of the homogenate was determined with a conductivity meter (MeterLab PHM210, Radiometer analytical S.A., France). Three replicates were prepared for each sample. Conductivity was converted to $\mathrm{NaCl}$ equivalent through a standard curve constructed with $\mathrm{NaCl}$ solution (0-500 mM).

\section{Statistics and expression of data}

All experiments were made in triplicates if not described differently. The algae-water slurries were not homogenous and needed extensive mixing before sampling to obtain repeatable results. Depending on experiment, the data is expressed as milligram protein per gram algal biomass, protein solubility percentage:

\section{Solubility $(\%)$ \\ $=\mathrm{C}_{\text {soluble proteins in supernatant }} / \mathrm{C}_{\text {total protein in homogenate }} \times 100$}

or protein yield percentage:

\section{Yield $(\%)$}

$=\mathrm{M}_{\text {extracted protein in supernatant }} / \mathrm{M}_{\text {total protein in homogenate }} \times 100$
To statistically verify the differences between means, we used SPSS (IBM, USA) software to calculate the statistical significance with independent sample $t$ test. The equality of variances between groups was calculated with Levene's test.

\section{Results}

\section{Method for total protein determination}

To find a simple, yet reliable analysis method for determination of total protein concentration in algal samples and extracts/pellets thereof, we compared different extraction procedures, in combination with the Lowry quantification principle. The latter method has been shown previously to be more suitable for protein analysis of algal biomass than the Bradford method (Barbarino and Lourenco 2005).

Water extraction of samples at a high $\mathrm{pH}(>\mathrm{pH} 11)$ or at high temperature $\left(80^{\circ} \mathrm{C}\right)$ gave a low protein yield, as compared to the $84 \mathrm{mg}$ protein $\mathrm{g}^{-1}$ biomass that was revealed by the reference total nitrogen analysis by Kjeldahl (Fig. 2). A harsher method of boiling the samples at their native $\mathrm{pH}$ in $2 \% \mathrm{SDS}$ and $1 \mathrm{mM}$ DTT, on the other hand, yielded $88 \mathrm{mg} \mathrm{g}^{-1}$ biomass, which is comparable to the value 


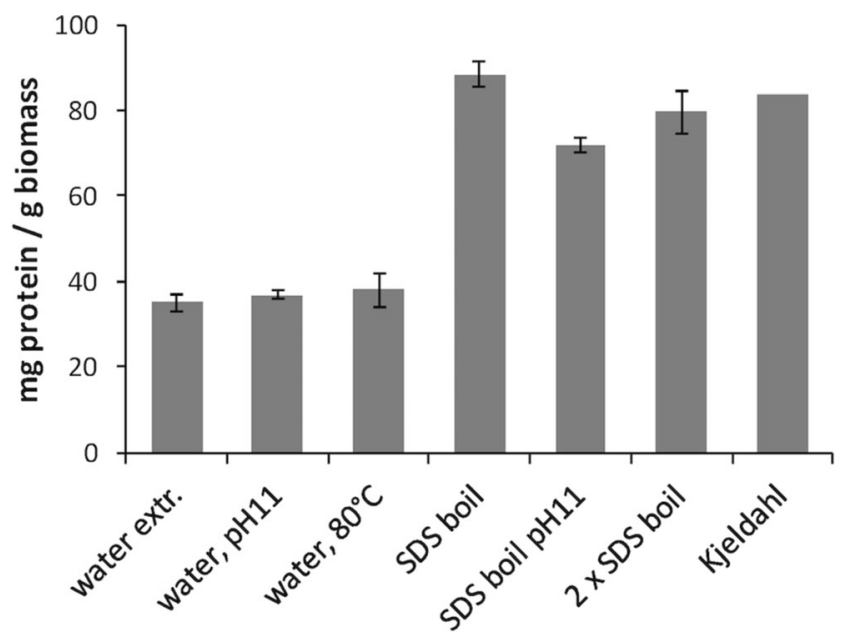

Fig. 2 Assessment of extraction methods for total protein analysis. Different methods for extracting total protein for subsequent Lowry analysis were compared. Freeze-dried and finely ground algal biomass was subjected to extraction by (1) water, room temperature, $1 \mathrm{~h}$; (2) water, $\mathrm{pH} 11$, room temperature, $1 \mathrm{~h}$; (3) water, $80^{\circ} \mathrm{C}, 1 \mathrm{~h}$; (4) $2 \% \mathrm{SDS}+1 \mathrm{mM}$ dithiothreitol (DTT), $100{ }^{\circ} \mathrm{C}, 3 \times 5 \mathrm{~min}$; (5) $2 \% \mathrm{SDS}+1 \mathrm{mM}$ DTT, $\mathrm{pH} 11,100{ }^{\circ} \mathrm{C}, 3 \times 5 \mathrm{~min}$; and (6) $2 \% \mathrm{SDS}+1 \mathrm{mM} \mathrm{DTT}$, pH 11, $100{ }^{\circ} \mathrm{C}$, $3 \times 5 \mathrm{~min}$ in two steps. The same biomass was analyzed with (7) Kjeldahl method, for comparison

calculated from Kjeldahl-derived total nitrogen values. Increasing the $\mathrm{pH}$ of the extraction solution to $\mathrm{pH} 11$ did not further improve the extraction. Since the boiling in SDS gave a value that was comparable to the result from the analysis according to the Kjeldahl method, this method was used for protein determination throughout the experiments.

\section{Optimization of $\mathrm{pH}$ for algal protein solubilization in water}

To map the protein solubility in water at different $\mathrm{pH}$ values, for accurate design of the extraction procedure, algal biomass was homogenized in water at a ratio of $1: 4(w / w)$, and $\mathrm{pH}$ was adjusted to values between 2 and 12 as indicated in Fig. 3. Our results showed that the solubility peaked at $\mathrm{pH} 12$, with over $100 \%$ solubility. This slight overestimation could be due to sampling differences, since the algal slurry was not absolutely homogenous. The solubility was decreasing with decreasing $\mathrm{pH}$ values, eventually plateauing at $\mathrm{pH} 2-3$, where the solubility was only about $30 \%$. The pattern of protein solubility of the macroalgal biomass differs from those reported, for example, for nuts (Ramos and Bora 2004), whey (Mulcahy et al. 2016) and fish (Undeland et al. 2003), the curves of which were U-shaped with a clear dip in solubility around $\mathrm{pH} 4-6$. It is, however, in accordance with other studies of marine algal proteins, with the same slope-shaped solubility curves. For instance, the solubility of Nannochloropsis oculata protein has been shown to remain low from $\mathrm{pH} 3$ down to 1 (Cavonius et al. 2015). The isoelectric point (pI) generally appears to be lower in algae proteins than in other biomasses;

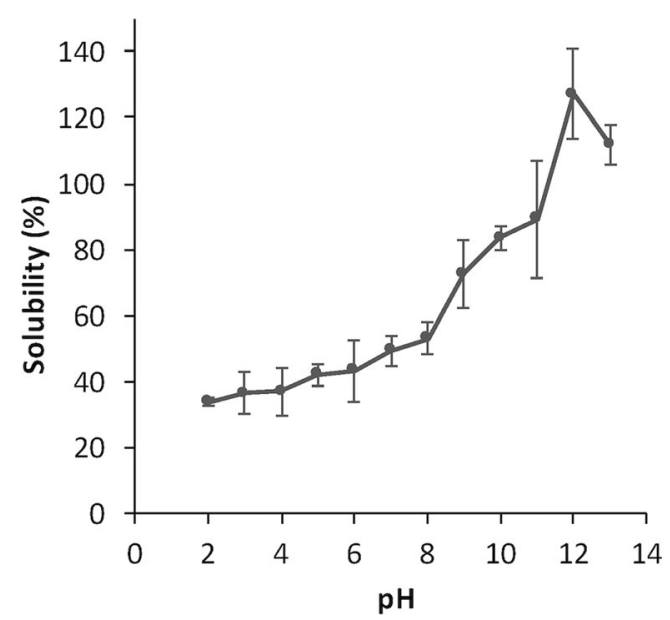

Fig. 3 pH-dependent solubility. Slurries with homogenized algal biomass and water in a ratio of 1:4 were incubated at different $\mathrm{pH}$ values, before separating liquid and solid material by centrifugation. Total protein content and solubilized proteins were quantified, and the solubility is expressed as a percentage as calculated from the extract concentration divided by the total protein concentration of the original slurry. All experiments are performed in triplicates, and the error bars represent standard deviations

values of $\mathrm{pH} 3.5$ for Scenedesmus acutus (Venkataraman and Shivashankar 1979), pH 3.0 for Spirulina platensis (Devi et al. 1981), and pH 4 for Tetraselmis sp. (Schwenzfeier et al. 2011) have been reported, but the lack of increase in solubility at lower $\mathrm{pH}$ seems to be unique for the marine species. This is probably an effect of the salt concentrations in the experiments, the interaction of anions with positively charged groups of proteins at low $\mathrm{pH}$ being a well-known mechanism pushing the pI downwards (Belitz et al. 2009).

Since the pH-dependent protein solubility is known to be affected by the ionic strength, we analyzed the salinity of the algal biomass. The conductivity, as expressed in $\mathrm{NaCl}$ equivalents, was as high as $525 \pm 8.28 \mathrm{mM}$ in the wet biomass, which means $80 \mathrm{mM}$ in a 1:5.56 water homogenate. This reflects the enrichment of minerals (e.g. $\mathrm{Na}, \mathrm{K}, \mathrm{Mg}, \mathrm{Ca}$ ) in brown seaweed (Ruperez 2002) and their counter anions, and could be the cause of the low solubility at low $\mathrm{pH}$ and lack of distinct $\mathrm{pI}$ in our study. It has, in fact, been shown previously, with Tetraselmis sp., that the ionic strength could affect the solubility. In that study, it was shown not only that higher salt concentrations lowered the solubility at low $\mathrm{pH}$ values but also that they cause a lack of a distinct pI value. Kumar et al. (2014) saw that the water solubility of a protein concentrate from $K$. alvarezii between $\mathrm{pH} 2$ and 12 was ranked as follows: pure water $>0.1 \mathrm{M} \mathrm{NaCl}>0.5 \mathrm{M} \mathrm{NaCl}$.

\section{Extraction of algal proteins using the reference/basic protein extraction sequence}

Using the described basic extraction sequence, a protein solubility of $34 \%$ was achieved during the water incubation (i.e. 
the osmotic shock). Measuring the concentration of solubilized proteins after the second, alkaline extraction of the residual pellet from the first step, revealed a concentration of solubilized protein that was $29 \%$ of that in the initial homogenate. Subtracting the volume loss from the removal of the pellets, the final total protein yields of the two steps were 25 and $20 \%$, respectively. The difference between protein solubilities in the two steps, 34 and $29 \%$, and total protein yields in the same steps reflect the retaining of protein-containing liquid in the pellet. The size of this loss could be dependent on several factors, such as water-holding capacity and centrifugation parameters.

\section{Effect of varying the length osmotic shock on the extraction yield}

The osmotic shock was carried out to break cells, to facilitate the liberation of the algal proteins. To investigate the effect of the length of the osmotic shock on the amount of proteins solubilized by water and subsequently alkali, the length of the initial water incubation was varied from 0 to $16 \mathrm{~h}$ as shown in Fig. 4a. It appeared that the water incubation had a clear positive effect on the extractability but that it did not need to be long; there was no difference between 1- and 2-h incubations. These two incubation times gave total protein yields of 46 and $45 \%$ after the subsequent alkaline extraction. There was a significant decrease in total extractability after the longest incubation that lasted $16 \mathrm{~h}$, albeit the relative protein extractability in water was not significantly different from 1 and $2 \mathrm{~h}$ of osmotic shock. In the reference sample $(0 \mathrm{~h})$, which was not subjected to an osmotic shock prior to alkaline extraction, only $34 \%$ of the total protein could be extracted.

\section{Effect of volume on extraction yield}

The ratio between biomass and extraction liquid is known to be a factor that can affect the extraction yield. This is because more water allows for better solubility (Stefansson and Hultin 1994) and also creates a more diluted system, which causes less solubilized proteins to be retained in the pellet (Vareltzis and Undeland 2012). A higher proportion of water will also lower the ionic strength of the system, which could either increase or decrease protein solubility, depending on the shape of the salting-in/salting-out curve. In our study, we saw a positive effect on the extraction yield when the relative amount of water was increased from 1:20 to 1:60 (dw basis) (Fig. 4b). The effect was not pronounced, but still significant $(p<0.05)$. Just comparing the means, there was also an increase in extraction yield when the water ratio was increased from 1:40 to 1:60; this could, however, not be confirmed statistically, probably because of high variation between the replicates. When increasing the extraction volume to $1: 60$, especially the water extraction (i.e. the osmotic shock step) was positively affected with a $58 \%$ increase in yield, compared to the reference extraction with 20 parts of water. The alkaline extraction, in fact, gave a somewhat lower yield at a 1:60 ratio, but the overall extraction yield was $59.5 \%$, which exceeds the yield obtained with the basic extraction protocol by $14.4 \%$.

\section{Effect of temperature on solubility}

The temperature can be important for protein solubilization, and elevated temperatures can decrease solubility due to protein denaturation (González-Quijada et al. 2003). Denaturation is known to take place at lower temperatures, e.g. in fish compared to in warm-blooded animals (Howell et al. 1991). Our hypothesis was that algae, adapted to cold temperatures, would be less extractable at 20 or $50{ }^{\circ} \mathrm{C} \mathrm{com}$ pared to at $4{ }^{\circ} \mathrm{C}$. However, in our experiments (Fig. 4c), there was no significant effect when varying the temperature between 4,20 and $50{ }^{\circ} \mathrm{C}$. Only in the initial water extraction, there was a slightly higher solubility at $50{ }^{\circ} \mathrm{C}$, but this was balanced by a less effective alkaline extraction at this
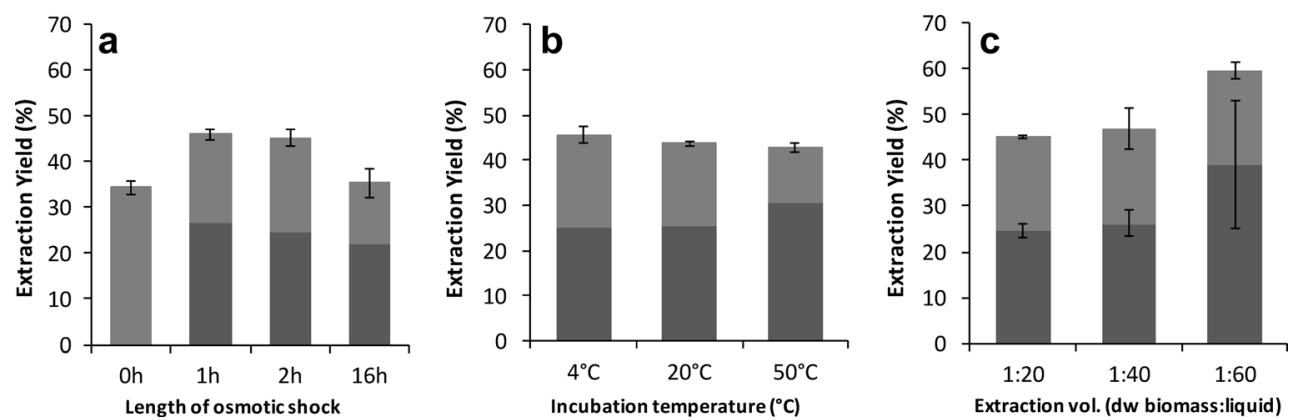

Fig. 4 Effect on protein extraction yield of (a) length of osmoshock (using 1:20 dry biomass to water and incubation at $4{ }^{\circ} \mathrm{C}$ ), (b) extraction volume (using 2-h incubation at $4{ }^{\circ} \mathrm{C}$ ) and (c) temperature (using 1:20 dry biomass to water and 2-h incubation) on the efficiency of protein extraction. The dark grey bars represent the protein extracted in the separated water fraction (osmoshock), and the light grey bars represent the protein extracted in the alkaline fraction at $\mathrm{pH} 12$. In graph a, the $0-\mathrm{h}$ staple represents an experiment with no osmoshock but direct homogenization in alkaline conditions. All experiments were made in triplicates, and the error bars represent standard deviation 
temperature, so that the final extraction yield was similar to that of 4 and $20^{\circ} \mathrm{C}$. The findings that extraction temperature had very little effect on the yield could be seen as a promising result, since it points towards lower requirements for energy during industrial extraction.

Based on the previous results, we suggest an extraction process at room temperature, with an algae/water ratio of 1:20 and a short water incubation of around $1 \mathrm{~h}$ for osmotic shock. If fresh water is not a limiting factor, a higher yield is indeed given with 60 volumes of water. Expressing the protein yields obtained with $20 \mathrm{vs} 60$ parts of water per $100 \mathrm{~g}$ ingoing dry algal biomass gives 3.98 and $5.25 \mathrm{mg} \mathrm{g}^{-1}$, numbers that can be compared with those of Harnedy and Fitzgerald (2013) working with $P$. palmata. They obtained a mean alkalinesoluble protein recovery of 5.76, 6.18 and $8.39 \mathrm{~g}(100 \mathrm{~g})^{-1}$ dry algae weight, with osmotic shock, high shear treatments or addition of polysaccaridase enzymes (e.g. Celluclast $1.5 \mathrm{~L}$ and Shearzyme $500 \mathrm{~L}$ ), respectively, to break down the cellular structures. Considering that the red seaweed P. palmata is known to be a more protein-rich species than brown seaweeds like Saccharina latissima (Fleurence 1999), the two-step extraction procedure in our study can be considered reasonably efficient.

\section{Precipitation at different $\mathrm{pH}$ values}

To investigate a route to concentration of algal proteins based on alkali-aided solubilization, followed by isoelectric precipitation, the effect of $\mathrm{pH}$ on protein solubility in the acid range was investigated (Fig. 5). To better approach a putative

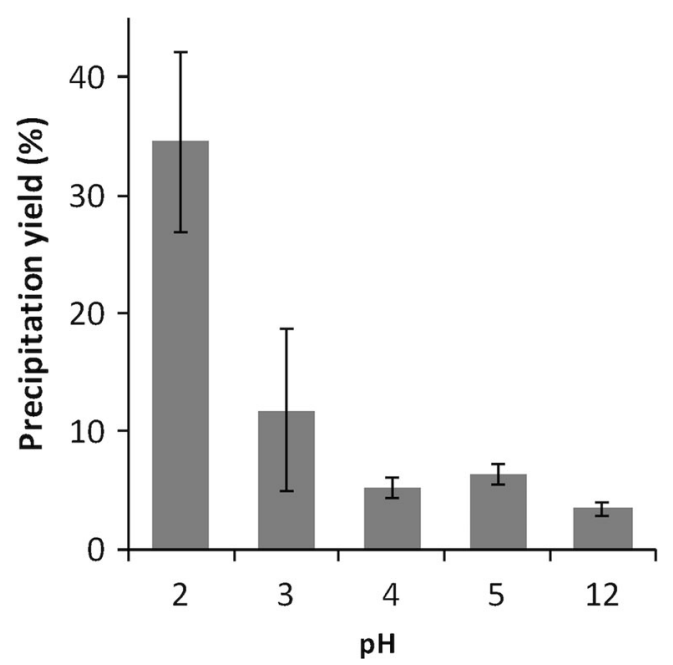

Fig. 5 Efficiency of precipitation at different $\mathrm{pH}$ values. Aliquots of a protein extract of $0.81 \mathrm{mg} \mathrm{mL}^{-1}$ algal protein were subjected to a lowering of the $\mathrm{pH}$ to 5 through 2 , and the precipitated protein fraction was separated by centrifugation. Yields are expressed as the percentage of the total protein content, in the original extract, that was retained in the pellets after separation. The original extract with a $\mathrm{pH}$ value of 12 was used as a control. All experiments were performed in triplicates, and the error bars represent standard deviations industrial procedure, the extraction sequence was adjusted so that the water fraction was not separated after the osmotic shock but adjusted directly to $\mathrm{pH} 12$, for a sequential alkaline extraction. After a centrifugation step, the alkaline extract was divided into aliquots for the precipitation experiment, with adjustment of $\mathrm{pH}$ to values from 2 to 5 . At $\mathrm{pH} 4$ and above, there was no protein precipitation as compared to the control (pH 12), whereas at $\mathrm{pH} 3$ and $\mathrm{pH} 2,11.7$ and $34.5 \%$ of the solubilized proteins were precipitated, respectively (Fig. 5).

The extraction yield of the water/alkali solubilization procedure $\left(1: 20,2\right.$-h osmoshock, $\left.20^{\circ} \mathrm{C}\right)$ was $46.4 \%$, meaning that $33.6 \mathrm{mg}$ of the ingoing $72.4 \mathrm{mg}$ protein of the algal biomass could be released by extraction. In the following precipitation, $\mathrm{pH} 2$ gave the highest yield, with precipitation of $34.5 \%$ of the solubilized proteins. The overall isolation yield from our $\mathrm{pH}$ shift procedure was thus $16.01 \%$. In the work by Kandasamy et al. (2012), in which proteins were dissolved at pH 12 with 2-mercaptoethanol and precipitated with ammonium sulphate, 'the percentage of recovered protein concentrate' in three species of green seaweed was from 5.71 to $6.48 \%$; it is, however, not clear if this is a per weight unit or per total initial protein. The concentrates contained from 33.4 to $60.4 \%$ protein (dw basis). Kumar et al. (2014), using the same protocol, reported on $7.81 \%$ recovery of protein concentrate from $K$. alvarezii and the concentrate contained $62.3 \%$ protein. Wong and Cheung (2001), also applying the same protocol, reported $7.8-48 \%$ protein recovery from dried Sargassum species. They found a negative correlation $(r=-0.96)$ between protein extractability and the total phenolic compound level in the range 10.5 to $24.5 \mathrm{mg}_{\text {phenolics }}{ }^{-1}$ $\mathrm{dw}$ of the three species dried with two different drying methods (freeze drying, oven drying). Phenolics may form reversible hydrogen bonds with proteins or oxidize to quinones, which irreversibly can bind to proteins, limiting protein extractability. Saccharina latissima harvested on the Swedish west coast in the late fall, as in this study, has previously been reported to contain $8.2 \mathrm{mg}$ phenolic compounds $\mathrm{g}^{-1} \mathrm{dw}$ (Veide Vilg et al. 2015), and such molecules could, indeed, be a factor that negatively affects the extractability, also in this study. With regard to all the listed studies, it should be stressed that ammonium sulphate-driven precipitation, however, reinforces the need for an extra dialysis step that complicates the process.

Calculating with a dry weight protein content of $9 \%$, as in our biomass, and a production yield of $130 \mathrm{t}$ of cultivated kelp biomass per hectare (Kraan 2013), $18 \%$ dry matter and a $16 \%$ extraction yield would give around $340 \mathrm{~kg}$ protein per hectare of cultivation. To reach the level of productivity from soy cultivation, which is around $400 \mathrm{~kg}$ (edible) soy protein per hectare (Kaldy 1972), an extraction yield of at least $19 \%$ needs to be achieved. There are several factors that could be investigated to improve the yield. In our experiments, we used relatively low g-forces during centrifugation; applying a more forceful centrifugation could give a more efficient separation 
of the liquid from the solid phase, with less retention of solubilized protein in the pellet as an effect. We can also hypothesize that the use of carbohydrate-degrading enzymes, specifically alginate lyases, would lower the water-holding capacity of the pellet, due to the degradation of the highly gelling kelp compound alginate. Another possible effect of addition of carbohydrate-degrading enzymes could be that their degradation of structural components of the cell wall would increase the release of proteins into solution. It was previously shown that a very high enzyme concentration was needed to achieve any effect on protein yield (Harnedy and FitzGerald (2013), but since the enzyme formulas used in that report were designed for degradation of terrestrial plant material, the general effect of enzymatic treatment could be underestimated. To clarify the feasibility of enzymatic degradation of algal biomass for protein extraction, the enzyme mixtures would need to be tailor-made for the composition of the cell walls of the specific algal species. The precipitation yield could also possibly be improved by adding, e.g. flocculating/precipitating agents, provided they are food grade and thereby acceptable in the final product. As for the separation following extraction, the g-forces of centrifugation could be increased also for the precipitation step, to improve the overall yield. This would, however, increase the energy costs. Other possible adjustments could be to lengthen the precipitation incubation period and to lower the temperature. Further investigations are thus needed to develop an optimal protein concentration protocol for Saccharina latissima, but this study can be seen as an initial mapping of factors influencing the procedure.

\begin{abstract}
Acknowledgments The authors would like to thank Mehdi Abdollahi Khozaghi and Hanna Harrysson at Food and Nutrition Science, Chalmers University of Technology, for kind help with salinity analyses and statistical calculations, respectively. We would also like to thank Göran Nylund, Gunnar Cervin and Henrik Pavia at Sven Lovén Centre for Marine Sciences (Tjärnö), University of Gothenburg, for supplying the algal biomass. The study was funded by the Swedish Research Council Formas and conducted within the project 'Seafarm', Grant no. 20132013-92.
\end{abstract}

Open Access This article is distributed under the terms of the Creative Commons Attribution 4.0 International License (http:// creativecommons.org/licenses/by/4.0/), which permits unrestricted use, distribution, and reproduction in any medium, provided you give appropriate credit to the original author(s) and the source, provide a link to the Creative Commons license, and indicate if changes were made.

\section{References}

Barbarino E, Lourenço SO (2005) An evaluation of methods for extraction and quantification of protein from marine macro- and microalgae. J Appl Phycol 17:447-460

Belitz HD, Grosch W, Schieberle P (2009) Food chemistry, 4th edn. Springer, Berlin

Bixler HJ, Porse H (2011) A decade of change in the seaweed hydrocolloids industry. J Appl Phycol 23:321-335
Bogolitsyn KG, Kaplitsin PA, Pochtovalova AS (2014) Amino-acid composition of arctic brown algae. Chem Nat Compd 49:1110-1113

Boland MJ, Rae AN, Vereijken JM, Meuwissen MPM, Fischer ARH, van Boekel MAJS, Rutherfurd SM, Gruppen H, Moughan PJ, Hendriks WH (2013) The future supply of animal-derived protein for human consumption. Trends Food Sci Tech 29:62-73

Cavonius LR, Albers E, Undeland I (2015) pH-shift processing of Nannochloropsis oculata microalgal biomass to obtain a proteinenriched food or feed ingredient. Algal Res 11:95-102

Cavonius LR, Albers E, Undeland I (2016) In vitro bioaccessibility of proteins and lipids of $\mathrm{pH}$-shift processed Nannochloropsis oculata microalga. Food Funct. doi:10.1039/C5FO01144B

Daroch M, Geng S, Wang G (2013) Recent advances in liquid biofuel production from algal feedstocks. Appl Energy 102:1371-1381

Devi MA, Subbulakshmi G, Devi KM, Venkataraman LV (1981) Studies on the proteins of mass-cultivated, blue-green alga (Spirulina platensis). J Agric Food Chem 29:522-525

Fleurence J (1999) Seaweed proteins: biochemical, nutritional aspects and potential uses. Trends Food Sci Tech 10:25-28

Fleurence J, Le Coeur C, Mabeau S, Maurice M, Landrein A (1995) Comparison of different extractive procedures for proteins from the edible seaweeds Ulva rigida and Ulva rotundata. J Appl Phycol 7:577-582

González-Quijada MR, Alanís-Guzman MG, Serna-Saldivar SO (2003) Ebony (Phitecellobium flexicaule Benth) and proteins fractionation, solubilization, characterization and production of an isolate. Arch Latinoam Nutr 53:84-89

Harnedy PA, FitzGerald RJ (2013) Extraction of protein from the macroalga Palmaria palmata. LWT-Food Sci Technol 51:375-382

Harnedy PA, FitzGerald RJ (2015) Extraction and enrichment of protein from red and green macroalgae. In: Stengel DB, Connan S (eds) Natural products from marine algae: methods and protocols. Springer Science, Berlin, pp. 103-108

Horie Y, Sugase K, Horie K (1995) Physiological differences of soluble and insoluble dietary fibre fractions of brown algae and mushrooms in pepsin activity in vitro and protein digestibility. Asia Pac J Clin Nutr 4:251-255

Hou X, Hansen JH, Bjerre A-B (2015) Integrated bioethanol and protein production from brown seaweed Laminaria digitata. Bioresource Technol 197:310-317

Howell BK, Matthews AD, Donnelly AP (1991) Thermal stability of fish myofibrils: a differential scanning calorimetric study. Int J Food Sci Tech 26:283-295

Hughes AD, Kelly MS, Black KD, Stanley MS (2012) Biogas from macroalgae: is it time to revisit the idea? Biotechnol Biofuels 5:86

Hultin HO, Kelleher SD (1999) Protein composition isolated from a muscle source US Patent 6005073

Hultin HO, Kelleher SD (2000) High efficiency alkaline protein extraction. US Patent 6136959

Hultin HO, Kelleher SD (2001) Process for isolating a protein composition from a muscle source and protein composition. US Patent 6288216B1.

Hultin HO, Kelleher SD, Feng Y, Kristinsson HG, Richards MP, Undeland IK, Ke S (2000) High efficiency alkaline protein extraction. US Patent Appl 60/230397.

Jónsdóttir R, Geirsdóttir M, Hamaguchi PY, Jamnik P, Kristinsson HG, Undeland I (2016) The ability of in vitro antioxidant assays to predict the efficiency of a cod protein hydrolysate and brown seaweed extract to prevent oxidation in marine food model systems. J Sci Food Agric 96:2125-2135

Jordan P, Vilter H (1991) Extraction of proteins from material rich in anionic mucilages: partition and fractionation of vanadatedependent bromoperoxidases from the brown algae Laminaria digitata and L. saccharina in aqueous polymer two-phase systems. Biochim Biophys Acta - Gen Subj 1073:98-106 
Kaldy MS (1972) Protein yield of various crops as related to protein value. Econ Bot 26:142-144

Kandasamy G, Karuppiah SK, Rao PVS (2012) Salt-and pH-induced functional changes in protein concentrate of edible green seaweed Enteromorpha species. Fisheries Sci 78:169-176

Kjeldahl J (1883) Neue Methode zur Bestimmung des Stickstoffs in organischen Körpern (New method for the determination of nitrogen in organic substances). Z Anal Chem 22:366-383

Kraan S (2013) Mass-cultivation of carbohydrate rich macroalgae, a possible solution for sustainable biofuel production. Mitig Adapt Strateg Glob Change 18:27-46

Kumar KS, Ganesan K, Selvaraj K, Rao PS (2014) Studies on the functional properties of protein concentrate of Kappaphycus alvarezii (Doty) Doty—an edible seaweed. Food Chem 153:353-360

Liu FR, Chen ZX, Wang L, Wang R (2013) Effects of protein solubilisation and precipitation $\mathrm{pH}$ values on the functional properties of defatted wheat germ protein isolates. Int J Food Sci Technol 48:1490-1497

Lowry OH, Rosebrough NJ, Farr AL, Randall RJ (1951) Protein measurement with the Folin phenol reagent. J Biol Chem 193:265-275

Maehre HK, Malde MK, Eilertsen KE, Elvevoll EO (2014) Characterization of protein, lipid and mineral contents in common Norwegian seaweeds and evaluation of their potential as food and feed. J Sci Food Agr 94:3281-3290

Marinho GS, Holdt SL, Angelidaki I (2015) Seasonal variations in the amino acid profile and protein nutritional value of Saccharina latissima cultivated in a commercial IMTA system. J Appl Phycol 27:991-2000

Mulcahy EM, Mulvihill DM, O’Mahony JA (2016) Physicochemical properties of whey protein conjugated with starch hydrolysis products of different dextrose equivalent values. Int Dairy J 53:20-28

Ramos CMP, Bora PS (2004) Functional characterization of acetylated Brazil nut (Bertholletia excelsa HBK) kernel globulin. Food Sci Technol (Campinas) 24:134-138

Rickert DA, Meyer MA, Hu J, Murphy PA (2004) Effect of extraction $\mathrm{pH}$ and temperature on isoflavone and saponin partitioning and profile during soy protein isolate production. J Food Sci 69:C623-C631

Ruperez P (2002) Mineral content of edible marine seaweeds. Food Chem 79:23-26

Schwenzfeier A, Wierenga PA, Gruppen H (2011) Isolation and characterization of soluble protein from the green microalgae Tetraselmis sp. Bioresour Technol 102:9121-9127

Stefansson G, Hultin HO (1994) On the solubility of cod muscle proteins in water. J Agr Food Chem 42:2656-2664

Undeland I, Kelleher SD, Hultin HO (2002) Recovery of functional proteins from herring (Clupea harengus) light muscle by an acid or alkaline solubilization process. J Agric Food Chem 50:7371-7379

Undeland I, Kelleher SD, Hultin HO, Mc Clements J, Thongraung C (2003) Consistency and solubility changes in herring (Clupea harengus) light muscle homogenates as a function of $\mathrm{pH}$. J Agric Food Chem 51:3992-3998

Vareltzis PK, Undeland I (2012) Protein isolation from blue mussels (Mytilus edulis) using an acid and alkaline solubilisation technique - process characteristics and functionality of the isolates. $\mathrm{J}$ Sci Food Agric 92:3055-3064

Veide Vilg J, Nylund GM, Werner T, Qvirist L, Mayers J, Pavia H, Undeland I, Albers A (2015) Seasonal and spatial variation in biochemical composition of Saccharina latissima during a potential harvesting season for western Sweden. Bot Mar 58:435-447

Venkataraman LV, Shivashankar S (1979) Studies on the extractability of proteins from the alga Scenedesmus acutus. Algol Stud 22:114-126

Wong K, Cheung PC (2001) Influence of drying treatment on three Sargassum species 2. Protein extractability, in vitro protein digestibility and amino acid profile of protein concentrates. J Appl Phycol 13:51-58

Wu G, Fanzo J, Miller DD, Pingali P, Post M, Steiner JL, ThalackerMercer AE (2014) Production and supply of high-quality food protein for human consumption: sustainability, challenges, and innovations. Ann N Y Acad Sci 1321:1-19 